\title{
Sialolithiasis of minor salivary glands
}

\author{
Sialolitíase de glândulas salivares menores
}

Isabela Fernandes SOUZA'

Michele Montini KAWATAKE ${ }^{1}$

Andresa Borges SOARES 1

Paulo de Camargo MORAES ${ }^{1}$

Vera Cavalcanti de ARAÚJO'

Fabrício PASSADOR-SANTOS ${ }^{1}$

\begin{abstract}
Sialolithiasis, or salivary calculus, is a disease of the salivary glands, characterized by the formation of mineralized structures within the excretory salivary ducts or the glandular parenchyma. Approximately $80 \%$ occur in the submandibular gland, followed by the parotid and sublingual glands. Although rare, sialolithiasis can also occur in the minor salivary glands. Although the oral cavity and upper lip are the most common sites, they can develop in any region of the oral cavity that contains minor salivary glands. Treatment is based on surgical excision of the lesion, with a favorable prognosis. This study presents three cases of sialolithiasis of minor salivary glands of the upper and lower lip, addresses their clinical characteristics and correlation with microscopic findings, diagnosis and treatment plans. Etiology and factors that should be considered during diagnosis, appropriate treatment and improved prognosis are discussed in this study.
\end{abstract}

Indexing terms: Minor salivary glands. Oral pathology. Salivary gland calculi.

\section{RESUMO}

A sialolitíase, ou cálculo salivar é uma doença de glândulas salivares, caracterizada pela formação de estrutura mineralizada no interior dos ductos salivares excretores ou no próprio parênquima glandular. A glândula submandibular é acometida em aproximadamente $80 \%$ dos casos seguida das glândulas parótida e sublingual. Embora raro o cálculo salivar também pode ocorrer em glândulas salivares menores. O lábio superior e a mucosa oral são os sítios de envolvimento de maior frequência, embora possam desenvolver-se em qualquer região da cavidade oral que contenha glândulas salivares menores. O tratamento baseia-se na remoção cirurgia, com prognóstico favorável. Este artigo apresenta três casos raros de sialolitíase de glândula salivar menor localizados em lábio superior e inferior, abordando as características clínicas e sua relação com os achados microscópicos, diagnóstico e formas de tratamento. A etiologia da lesão e fatores que devem ser considerados para o diagnóstico, tratamento adequado e um melhor prognóstico são discutidos neste estudo.

Termos de indexação: Glândulas salivares menores. Patologia bucal. Cálculos das glândulas salivares.

\section{INTRODUCTION}

Sialolithiasis, or salivary gland calculus, is the terminology used to describe the formation of calculi, or sialoliths, within the excretory salivary ducts or the glandular parenchyma ${ }^{1-2}$ There are more commonly found in major salivary glands, being associated to the submandibular gland in $80 \%$, the parotid gland in $6-20 \%$ and the sublingual or minor salivary glands in only $2 \%$ of cases ${ }^{1,3-4}$ It more commonly affects middle-aged patients and, despite occurring in both genders, it has a slight male predominance ${ }^{5}$.
Clinically, a patient with minor salivary gland sialolithiasis usually presents with a palpable, firm, submucosal nodule. Although the upper lip and the buccal mucosa are the most frequently affected sites, they may develop in any part of the oral cavity that contains minor salivary glands ${ }^{1-5}$

Patients may complain of discomfort or mild pain during meals, accompanied by a sudden and recurring increase in size of the gland involved, followed by a gradual decrease ${ }^{6}$ In cases where the sialolith causes an obstruction, infection and/or sialoadenitis may occur ${ }^{7-8}$

\footnotetext{
${ }^{1}$ Instituto e Centro de Pesquisas São Leopoldo Mandic, Departamento de Patologia. Rua José Rocha Junqueira, 13, Swift, 13045-755, Campinas, SP, Brasil. Correspondência para / Correspondence to: IF SOUZA. E-mail: <isabela_odontologia@ig.com.br>.
} 
Radiographic examination reveals a radiopaque area measuring 0.3 to $1.5 \mathrm{~cm}$ in diameter with a mean of $0.61 \mathrm{~cm}^{9}$ A combination of clinical, radiographic and histological examinations is fundamental for diagnosis, due to the possibility of overlapping clinical characteristics common to other lesions. Treatment is based on surgical removal of both the sialolith and the gland involved, with a good prognosis ${ }^{2-4}$

The aim of this study was to report three rare cases of minor salivary gland sialolithiasis, which were treated surgically. In addition to performing a literature review and discuss the etiopathogenesis, diagnosis and treatment of this pathology.

\section{CASE REPORT}

\section{Case 1}

A 55-year-old, Caucasian, female patient presented to the Dental Clinic of São Leopoldo Mandic University, with a one month history of pain in the left region of the oral mucosa of the upper lip. Intra-oral examination revealed a mucosa-colored nodule measuring approximately $7 \mathrm{~mm}$. A differential diagnosis of pleomorphic adenoma and adenoid cystic carcinoma was proposed (Figure 1). A biopsy was performed and the specimen sent for histopathological examination.

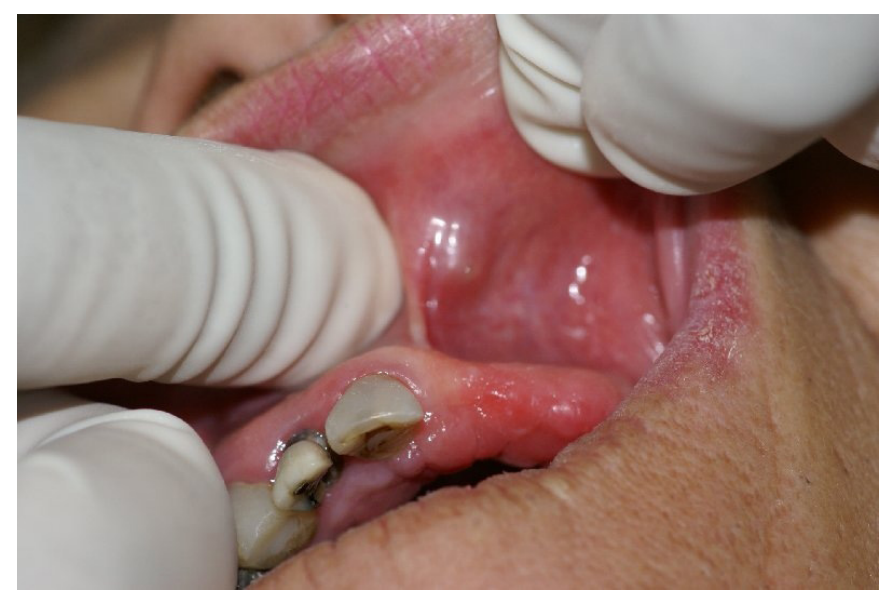

Figure 1. Intra-oral examination of the lesion during the first appointment suggested a clinical diagnosis of pleomorphic adenoma or adenoid cystic carcinoma. A mucosal-colored rubbery nodule is observed.

Macroscopic examination revealed a yellow/ grey rubbery rectangular fragment of soft tissue with an irregular surface, measuring $7 \times 6 \times 4 \mathrm{~mm}$ (Figure 2).

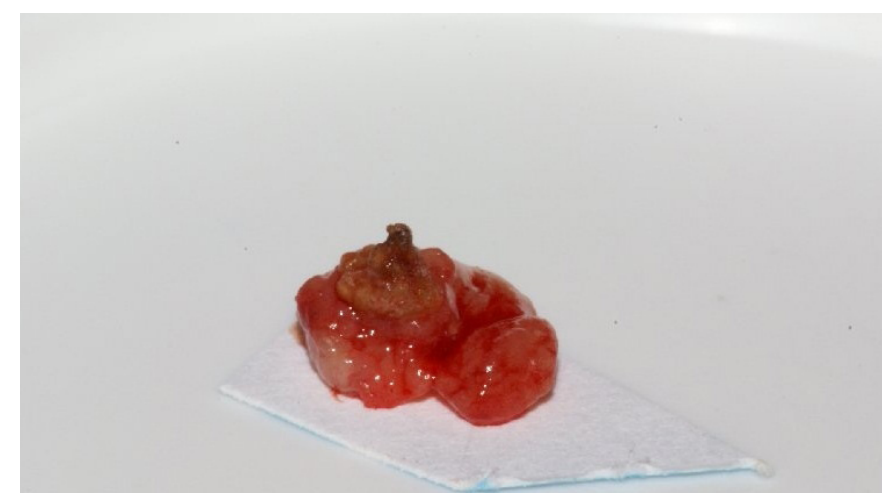

Figure 2. Surgical specimen revealing a rectangular yellow/red piece of the upper lip mucosa measuring $7 \times 6 \times 4 \mathrm{~mm}$, with an irregular surface.

Histological examination revealed a fragment of mucosa lined by a parakeratinized stratified squamous epithelium. The lamina propria consisted of a dense connective tissue, with a moderate inflammatory infiltrate composed of lymphocytes and plasma cells. Lobules of salivary glands were observed in the deeper aspects of the histological sections, which exhibited an intense chronic sialadenitis, as well as a basophilic calcified material deposited in a concentric pattern (Figure 3). The histopathology report was conclusive of minor salivary gland sialolithiasis.

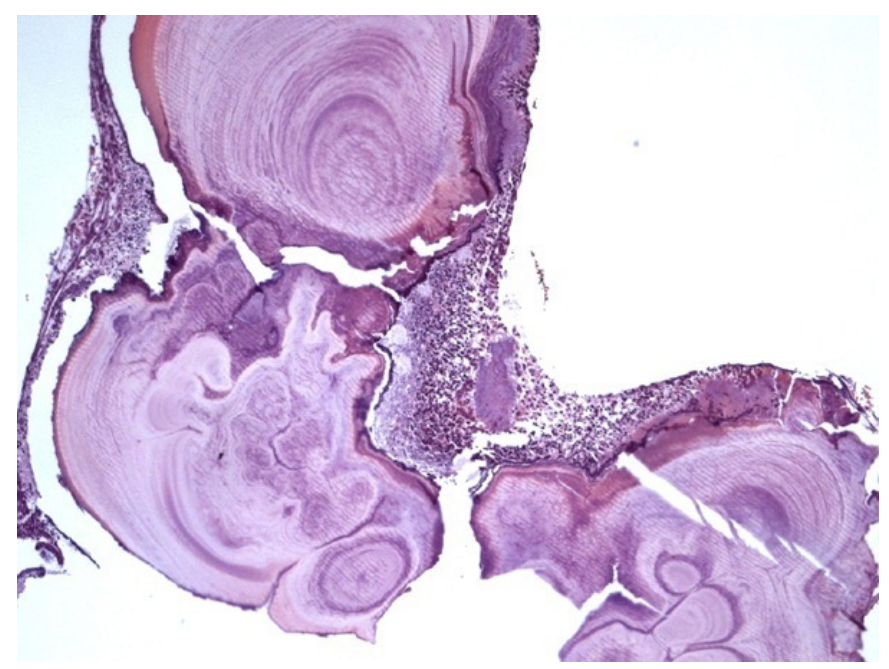

Figure 3. Histological section revealing a basophilic calcified material deposited in a concentric pattern.

\section{Case 2}

A 54-year-old, Caucasian, female patient presented to the Dental Clinic of the University of Santa Cecilia (Santos, SP), complaining of a one month history of pain in the right-sided oral mucosa of the lower lip. 
Intra-oral examination revealed a mucosa-colored nodule measuring approximately $10 \mathrm{~mm}$. A clinical differential diagnosis of neuroma or sialolith was suggested. An excisional biopsy was performed and the specimen sent for histopathological examination.

Macroscopic examination revealed three fragments of nodular, brownish, fibrous soft tissue, measuring $15 \mathrm{x}$ $10 \times 10 \mathrm{~mm}$, with an irregular surface.

Histopathological examination revealed a fragment of mucosa lined by a parakeratinized stratified squamous epithelium showing exocytosis. The lamina propria consisted of a dense connective tissue, where an intense lymphoplasmocytic inflammatory infiltrate was seen. Squamous metaplasia, the presence of calcified material and atrophied acinar showing a moderate sialadenitis were also observed. The histopathological diagnosis was sialolithiasis of the minor salivary gland.

\section{Case 3}

A 52-year-old Caucasian male patient attended a dental appointment at the Public Health Sector (Palmas, TO). Intra-oral examination revealed an asymptomatic, white-yellowish nodule on the upper lip, measuring approximately $3 \mathrm{~mm}$. A clinical differential diagnosis of sialolith was established. An excisional biopsy was performed and the specimen sent to the Oral Pathology Laboratory for histological examination.

Macroscopic examination revealed a fragment of whitish, nodular, hard tissue, measuring $5 \times 5 \times 5 \mathrm{~mm}$.

Histopathological examination revealed concentric calcifications, with the final diagnosis being sialolithiasis of the minor salivary gland.

All patients agreed to the use of their images for the present study, as well as signing an Informed Consent Form.

\section{DISCUSSION}

Although sialolithiasis may occur in any salivary gland, it is an uncommon finding in the minor salivary glands ${ }^{3-10}$ Studies with a higher number of cases (49- 76 cases) have suggested an increased prevalence in young and middle-aged males ${ }^{10-13}$ In the present study, two cases were in females, while only one was male, and all patients were considered middle-aged ( $52-55$ years).

The pathogenesis of sialoliths is not well understood, with researchers believing that they occur due to the deposition of calcium salts via debris encountered in the duct lumen, enabling the development of calcified structures with the salivary duct system ${ }^{14}$. Although not correlated with the described cases, trauma has also been suggested as a possible etiological factor, particularly where trauma has been caused by the dentition, such as the lips and the buccal mucosa close to the occlusal line ${ }^{12}$ In the present study, the lesions were found on the upper and lower lips, regions constantly subjected to trauma. However, none of the patients reported a history of trauma prior to the development of their lesions.

A sialolith may present in various sizes, with studies having reported their diameter as ranging from $0.3-1.5 \mathrm{~cm}$ (average $0.61 \mathrm{~cm}$ ) $1,11-13$ In sialolithiasis of the minor salivary glands, the most commonly affected regions are the upper lip (49.2\%), buccal mucosa (37.3\%), lower lip $(5.5 \%)$ and the buccal sulcus $(1.6 \%)^{5}$ The sialoliths described in the present study were located in either the upper or lower lip, ranging from 5 to $8 \mathrm{~mm}$.

Sialolithiasis of the minor salivary glands are usually described as rounded, oval or cylindrical, mobile, firm, asymptomatic nodules composed of hydroxyapatite crystals, with high concentrations of calcium and phosphorous ${ }^{15-17}$ The color of the nodules presented in the current study was variable, with mild or no symptoms. The presence of a sialolith-associated fistula is not a rare occurrence, according to the literature, which may be related to lesions that remain closer to the surface of the oral mucosa that facilitate trauma and secondary contamination ${ }^{16}$.

Radiographic examination is useful for diagnostic purposes, where occlusal and panoramic films are the most commonly used, with sialoliths presenting as a radiopaque areas $^{18}$ However, not all calculi are visible on conventional radiographs, which may be owing to a lesser degree of calcification in some lesions, hence other imaging modalities may be required, such as sialography, ultrasound, computed tomography or magnetic resonance imaging ${ }^{19}$. Radiopaque lesions should lead to a differential diagnosis that includes a sialolith, calcified lymph node, phlebolith and vascular calcification ${ }^{1,11}$

Sialolithiasis of the minor salivary glands may present with similar characteristic to other lesions, making their diagnosis more difficult. In a study of 49 cases of sialolithiasis of minor salivary glands, only $20 \%$ were correctly diagnosed by the dental surgeon'.

The coexistence of sialoliths and malignancies has also been recently reported, with multiple myeloma and lymphoma having been found in association with a parotid gland sialolith ${ }^{10,18}$ A case of sialolithiasis found in association with an adenoid cystic carcinoma of the submandibular gland has been recently reported ${ }^{22}$. 
In addition, traumatic neuroma ${ }^{20}$, a proliferation of neural tissue in reaction to a traumatic stimulus, has also been reported as a possible differential diagnosis when found on the lower lip, as mentioned in case 2 of the present study.

Differential diagnoses include neoplastic processes of the salivary gland, such as pleomorphic adenoma, the commonest salivary gland neoplasm, which presents clinically with similar characteristics as sialolithiasis, a firm, painless, slow-growing mass, as described in the first case of the current series. Other lesions include mucus cyst, irritation fibroma and mucocele ${ }^{21-22}$, which may present with similar characteristics to sialolithiasis of the minor salivary gland.

Although in the majority of cases, a clinical history, physical examination and radiography are sufficient to arrive at a diagnosis, histopathologic evaluation must be performed in order to confirm diagnosis ${ }^{4,15}$

Cases 1, 2 and 3 presented with histological characteristics of concentric calcifications that appeared to be surrounding an amorphous nest of debris. In cases where the duct is also removed, squamous and oncocytic metaplasia are also present $t^{1,4-15}$

A review of the clinical and histological aspects is important for a correct diagnosis and effective treatment. Treatment for sialolithiasis of the minor salivary glands usually consists of surgical removal under local anesthetic 4-22 which was the treatment of choice in the present study. Considering alternative treatment options, a small calculus located at the opening of the excretory duct may be approached conservatively via warm compresses, delicate massage and milking of the gland, in an attempt to expel the calculus via the glands excretory duct orifice $^{6-13-22}$. However, in most cases a surgical approach

\section{REFERENCES}

1. Anneroth G, Hansen LS. Minor salivar gland caculi. A clinical and histopathological study of 49 cases. Int Oral Surg. 1983;12(2):80-9.

2. Araújo NS, Araújo VC. Patologia bucal. São Paulo: Artes Médicas; 1984.

3. Harrison JD. Causes, natural history, and incidence of salivary stones and obstructions. Otolaryngol Clin North Am. 2009:42(6):927-47. doi: 10.1016/j.otc.2009.08.012

4. Alcure ML, Della Coletta R, Graner E, Di Hipolito O Jr, Lopes MA. Sialolithiasis of minor salivary glands: a clinical and histoplathological study. Gen Dent. 2005;53(4):278-81. is preferred, in terms of an excisional biopsy, owing to its similarity to other pathologies and the absence of classic radiographic characteristics.

Surgical removal of sialoliths of the minor salivary glands has been recommended by some authors as it reduces the possibility of recurrence when compared with a more conservative approach, therefore being the treatment of choice for these lesions ${ }^{5}$.

\section{CONCLUSION}

Sialolithiasis of the minor salivary glands is an infrequent event, which may present a diagnostic difficulty due to the overlap of clinical characteristics with other lesions. The present study reported the clinical and histopathological features of three cases of sialolithiasis of the minor salivary glands located in the upper and lower lips. They were treated via surgical removal of the lesion together with the affect gland. No recurrence was observed.

\section{Collaborators}

IF SOUZA participated in writing the manuscript and edited the histological images. MM KAWATAKE participated in writing the manuscript and edited the clinical images. $A B$ SOARES participated in writing the discussion. PC MORAES provided the clinical information and images, critically reviewed the article and made a fundamental contribution to the description of the clinical aspects, differential diagnosis and treatment plans. VC ARAÚJO participated in writing the manuscript. F PASSADOR-SANTOS supervised the authors and actively participated in the process of writing the article.

5. Ben Lagha N, Alantar A, Samson J, Chapireau D, Maman L. Lithiasis of minor salivary glands: current data. Oral Surg Oral Med Oral Pathol Oral Radiol Endod. 2005;100(3):345-8. doi: doi:10.1016/j.tripleo.2004.12.023

6. Zk J, Constantinidis J, Kydles S, Hornung J, Iro H. Clinical and diagnostic findings in sialolithiasis. HNO. 1999;47(11):963-9.

7. Ledesma-Montes C, Garcés-Ortíz M, Salcido-Garcia JF, Hernández-Flores F, Hernández-Guerrero JC. Giant sialolith: case report and review of the literature. J Oral Maxillofac Surg. 2007;65(1):128-30. doi:10.1016/j.joms.2005.10.053

8. Yamane GM, Scharlock SE, Jain R, Sunder-Ray M, Chaudhry AP. Intraoral minor salivary gland sialolithiasis. J Oral Med.1984;39(2):85-90 
9. Iro H, Schneider HT, Födra C, Waitz G, Nitsche N, Heinritz HH, et al. Shockwave lithotripsy of salivary duct stones. Lancet. 1992;339(8805):1333-6. doi: 10.1016/0140-6736(92)91968-E

10. Ho V, Currie WJ, Walker A. Sialolithiasis of minor salivary glands. Br J Oral Maxillofac Surg. 1992;30(4):273-5.

11. Nahieli O, Eliav E, Hasson O, Zagury A, Baruchin AM. Pediatric sialolithiasis. Oral Surg Oral Med Oral Pathol Radiol Endod. 2000;90(6):708-12.

12. Jensen JL, Howell FV, Rick GM, Correll RW. Minor salivary gland calculi. A clinico-pathologic study of forty seven new cases. Oral Surg Oral Med Oral Pathol. 1979;47(1):44-50.

13. Pullon PA, Miller AS. Sialolithiasis of accessory salivary glands. Rewiew of 53 cases, J Oral Surg. 1972; 30:832-4.

14. Lee LT, Wong YK. Pathogenesis and diverse histologic findings of sialolithiasis in minor salivary glands. J Oral Maxillofac Surg. 2010;68(2):465-70. doi: 10.1016/j.joms.2009.03.041

15. Neville BW, Damn DD, Allen CM, Bouquot JE. Patologia maxilofacial. $3^{\circ}$ ed. Rio de Janeiro: Elsevier; 2009.

16. Flaitz CM. Sialolithiasis involving the maxillary alveolar mucosa. Am J Dent. 2000;13(6):342-3.

17. Bsoul SA, Flint DJ, Terezhalmy GT, Moore WS. Sialolithiasis. Quintessence Int. 2003;34:316-7.
18. Flavia G, Capodiferro S, Turco M, Cortelazzi R. Lithiasis of minor salivar glands of the upper lip. Clinico-pathological report of a case with unsual presentation. Minerva Stomatol. 2004;53(4):179-83.

19. Rzymska-Grala I, Stopa Z, Grala B, Goł区biowski M, Wanyura H, Zuchowska A, et al. Salivary gland calculi: contemporary methods of imaging. 2010;75(3):25-37.

20. Anbinder AL, Paiva TV, Mariano RC, Quirino MR. Traumatic neuroma of the lower lip. West Indian Med J. 2009;58(6):604-6.

21. Batzakakis D, Apostolopouos K, Bardanis I. A case report of coexistence of a sialolith and an adenoid cystic carcinoma in the submandibular gland. Med Oral Pato Cir Bucal. 2006;11:286-8.

22. Okada H, Yokokawa M, Komiya M, Akimoto $Y$, Kaneda T, Yamamoto H. A rare case of sialolithiasis of the lower lip simulating a mucocele and review of the literature. Quintessence Int. 2011;42(7):589-94. 
